\title{
Short Communication \\ Evaluating the role of human papillomaviruses in conjunctival neoplasia
}

\author{
ML Tornesello', ML Duraturo', KM Waddell², B Biryahwaho ${ }^{3}$, R Downing $^{3}$, S Balinandi ${ }^{3}$, SB Lucas 4 , \\ L Buonaguro' and FM Buonaguro*,I \\ 'Viral Oncology and AIDS Reference Centre, National Cancer Institute 'Fond. Pascale', Cappella Cangiani, I-80 I 3 I Naples, Italy; ' Uganda Eye Project, \\ PO Box 4008, Kampala, Uganda; ${ }^{3}$ Uganda Virus Research Institute, PO Box 49, Entebbe, Uganda; ${ }^{4}$ Department of Histopathology, Guy's, King's \& \\ St Thomas' School of Medicine, St Thomas' Hospital, London SEI, UK
}

Mucosal, cutaneous and Epidermodysplasia verruciformis (EV)-related human papillomaviruses (HPVs) were searched by broadspectrum PCR in 86 conjunctival neoplasia biopsies and 63 conjunctival non-neoplastic control tissue from Ugandan subjects. Seven different EV-related HPV types, including a putative new HPV, and two mucosal HPVs were detected in 25\% (I 4 out of 56) of HIVpositive, in 10\% (three out of 30) of HIV-negative conjunctival neoplasia samples, and rarely (0-1.6\%) in control subjects. The absence of high-risk HPVs and the low detection frequency of EV-related HPV types in more advanced tumour stages (I0\%) raise doubts about their role in conjunctival carcinomas.

British Journal of Cancer (2006) 94, 446-449. doi: I0.1038/sj.bjc.660292I www.bjcancer.com

Published online 10 January 2006

(c) 2006 Cancer Research UK

Keywords: conjunctiva squamous cell carcinoma; conjunctival intraepithelial neoplasia; papillomavirus; human immunodeficiency virus; Uganda

Conjunctival squamous cell neoplasia embraces ocular surface epithelial premalignant dysplasias and invasive carcinoma (Blodi, 1973). The histological staging is classified, as in cervical squamous cell neoplasia, by the thickness of epithelial dysplastic changes and the tumour invasion into the substantia propria (Waring et al, 1984). Although rare in Europe and USA, conjunctival neoplasia has been reported to be relatively common in regions of sub-Saharan Africa since the 1960s (Templeton, 1973). An emerging miniepidemic of conjunctival tumours has been described in Rwanda, Uganda and Tanzania in association with the epidemic of HIV infection since the 1980s (AteenyiAgaba, 1995; Waddell et al, 1996; Newton et al, 2002). The spread of HIV in Uganda, indeed, probably accounts for much of the approximately eight-fold increase in the incidence of conjunctival carcinoma observed during the last 20 years (Wabinga et al, 2000). So far the aetiology of conjunctival neoplasia is not adequately understood, although the association with HIV infection is most likely mediated by the immunosuppression, as in the other HIVassociated cancers (Beral and Newton, 1998).

High-risk mucosal human papillomavirus (HPV) types 16 and 18 have been detected in tissue biopsies of conjunctival neoplasias, although with highly variable results (Waddell et al, 1996; Buonaguro et al, 2000; Eng et al, 2002; Moubayed et al, 2004). More recently, Ateenyi-Agaba et al (2004) reported the presence of a discrete number of Epidermodysplasia verruciformis (EV) HPV types in $86 \%$ of invasive conjunctival squamous cell carcinoma, of which HIV serology was unknown, strongly suggesting their possible role also in such tumours.

*Correspondence: Dr FM Buonaguro; E-mail: irccsvir@unina.it Received 17 October 2005; accepted 25 November 2005; published online 10 January 2006
We have analysed conjunctival neoplasia biopsies at different stages of malignancy (from conjunctival intraepithelial lesions grade 1 (CIN1) to invasive conjunctival squamous cell carcinoma (ICSCC)) to determine the prevalence of mucosal, cutaneous as well as EV-related HPV types in such lesions and their association with the tumour progression in HIV-positive as well as HIVnegative patients.

\section{PATIENTS AND METHODS}

In total, 125 consecutive patients clinically diagnosed with conjunctival neoplasia at seven countrywide eye clinics in Southern Uganda, as part of the Ugandan Ruharo Eye Project, were enrolled as cases for this study between January 1997 and March 1999. The 125 cancer-free controls, frequency matched to the cases by sex and age ( \pm 10 years), were consecutively randomly enrolled from a pool of patients treated for benign eye lesions (i.e., pterygium) or eye injuries, within the same period of time, in the same eye clinics. All enrolled subjects, representing more than $95 \%$ of those approached, agreed to provide informed consent to participate. Blood serum samples were prospectively obtained from all cases (patients) as well as control subjects and analysed for HIV serology (ELISA screening followed by Western blot confirmation). The histological evaluation confirmed a total of 118 case biopsies as conjunctival neoplasias, the remaining seven were not confirmed as neoplastic tissue and excluded from the analysis.

DNA was extracted by digestion with proteinase $\mathrm{K}\left(150 \mu \mathrm{g} \mathrm{ml}^{-1}\right.$ at $60^{\circ} \mathrm{C}$ for $\left.30 \mathrm{~min}\right)$ in lysis buffer $(10 \mathrm{~mm}$ Tris- $\mathrm{HCl} \mathrm{pH} \mathrm{7.6,5 \textrm {mm }}$ EDTA, $150 \mathrm{~mm} \mathrm{NaCl}, 1 \%$ SDS), followed by DNA purification, phenol and phenol-chloroform-isoamyl alcohol $(25: 24: 1)$ extraction and ethanol precipitation in $0.3 \mathrm{~m}$ sodium acetate $(\mathrm{pH} 4.6)$. 
DNA quality test, performed by amplification with specific oligoprimers targeting a fragment of the exon 7 within the TP53 gene, and DNA quantity analysis, evaluated by spectrophotometric measurements, rendered 86 cases and 63 controls suitable for the HPV detection. Testing for HPV was carried out with generalprimer-mediated PCR using the following primer pairs: (a) MY09/ MY11 (Resnick et al, 1990) and (b) GP5 + /GP6 + (de Roda Husman et al, 1995), which preferentially amplify mucosal HPVs; (c) CP65/CP70 followed by CP66/CP69 for the amplification of EVrelated HPV types (Berkhout et al, 1995); (d) FAP59/FAP64 for the amplification of 75 different types of mucosal, cutaneous and EVrelated HPVs (Forslund et al, 1999). In addition, we used typespecific PCR targeting E6 genes of individual HPV16 and HPV38 types (Tornesello et al, 2000; Caldeira et al, 2003). Serial dilution (from one to 1000 copies) of 11 plasmid clones, containing HPV genomes representative of mucosal (HPV6, 11, 16, 18, 31, 33), cutaneous (HPV10), mucocutaneous (HPV2) and EV-related (HPV5, 8, 38) HPV types, were used as positive controls. Reaction mixtures without template DNA, included in every set of five clinical specimens, represented the negative controls. All amplified DNAs have been subjected to direct nucleotide sequence analysis following procedures previously described (Tornesello et al, 2000).

The data were analysed using $\chi^{2}$ test and, where appropriate, Fisher's exact test to calculate all $P$-values related to the differences between groups with Epi Info 6 Statistical Analysis System Software (6.04b, 1997, Centers for Disease Control and Prevention, USA). Differences were considered to be statistically significant when $P$-values were less than 0.05 .

Table I Distribution of known variables between conjunctival neoplasia cases and controls

\begin{tabular}{|c|c|c|c|}
\hline & $\begin{array}{c}\text { Conjunctival } \\
\text { neoplasia } n 86 \\
\text { (\%) }\end{array}$ & $\begin{array}{c}\text { Controls }{ }^{\mathrm{a}} \text { n } 63 \\
(\%)\end{array}$ & $P$ value \\
\hline Sex & & & 0.924 \\
\hline M & $35(40.7)$ & $27(42.8)$ & \\
\hline$F$ & $51(59.3)$ & $36(57.1)$ & \\
\hline Age & & & 0.955 \\
\hline$\leq 30$ years & $39(45.3)$ & $28(44.7)$ & \\
\hline$>30$ years & $47(54.6)$ & $35(55.3)$ & \\
\hline HPV PCR & & & 0.002 \\
\hline Positive & $17(19.8)$ & | (1.6) & \\
\hline Negative & $69(80.2)$ & $62(98.4)$ & \\
\hline HIV serology ${ }^{\mathrm{b}}$ & & & 0.01 \\
\hline Positive & $56(65.1)$ & $15(38.5)$ & \\
\hline Negative & $30(34.9)$ & $24(61.5)$ & \\
\hline HIV status & $\begin{array}{c}\text { Conjunctival } \\
\text { neoplasia } n 86 \\
\text { (\%) }\end{array}$ & $\begin{array}{c}\text { Controls }^{\mathrm{a}} \text { n } 39^{\mathrm{b}} \\
(\%)\end{array}$ & $P$ value \\
\hline HIV positive & & & $0.031^{c}$ \\
\hline HPV-Pos & $14(25.0)$ & $0(0.0)$ & \\
\hline HPV-Neg & $42(75.0)$ & $15(100)$ & \\
\hline HIV negative & & & $0.620^{c}$ \\
\hline HPV-Pos & $3(10.0)$ & I (4.2) & \\
\hline HPV-Neg & $27(90.0)$ & $23(95.8)$ & \\
\hline
\end{tabular}

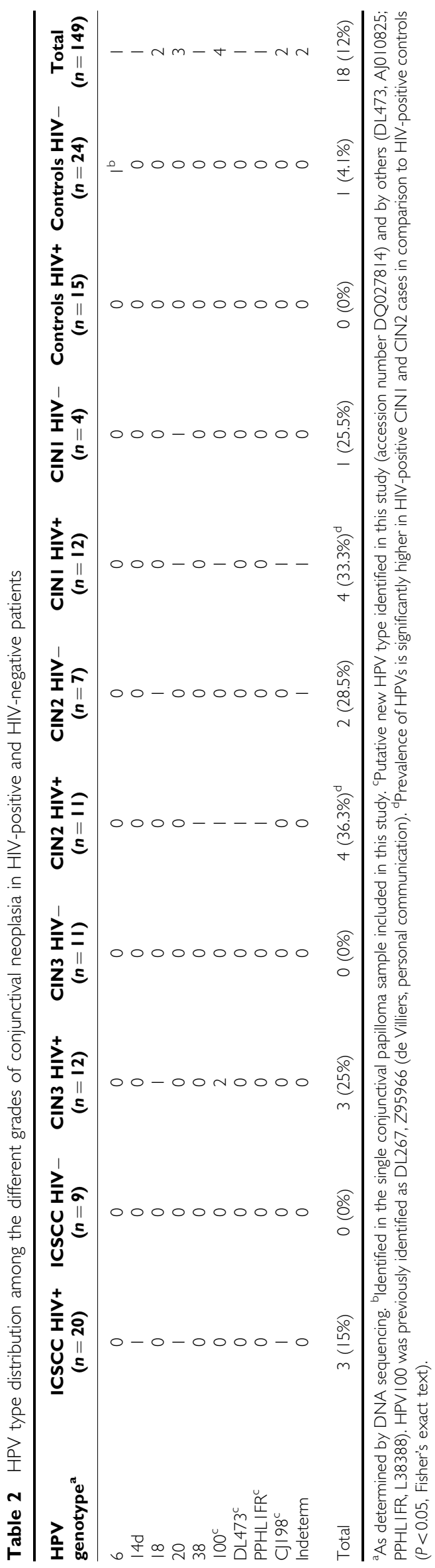




\section{RESULTS}

This study enrolled 125 cases with clinical presentations compatible with conjunctival neoplastic lesions and 125 control subjects. Following histological typing and DNA quality/quantity assays, 86 confirmed conjunctival neoplasia and 63 cancer-free control samples were included in the HPV screening. Table 1 summarises the selected characteristics of the subjects. There were no significant differences between cases and controls in the distribution of age and sex, suggesting that the frequency matching on these two variables were adequate. The median age was 32 years (mean $34.5 \pm 11.5$ years) for the cases, and 30 years (mean $35.6 \pm 10.7$ years) for the controls. The HIV seroprevalence among cases was significantly higher $(P=0.0095)$ than that observed in controls, confirming that HIV infection is a relevant risk factor in the pathogenesis of conjunctival carcinoma in this population (Table 1).

All 86 cases and 63 controls have been analysed by PCR using six primer sets to amplify mucosal, cutaneous as well as EV-related HPV types. Combining the results obtained with MY09/MY11, GP5 + /GP6 + , CP65/CP70-CP66/CP69 and HPV38 primer pairs, 18 samples were positive for the presence of HPVs (Table 1). No viral sequences were detected in either cases or control with FAP59/FAP64 and HPV16-specific primer pairs.

The HPV-positive samples comprise $17(19.8 \%)$ conjunctival neoplasia and one $(1.6 \%)$ control biopsy $(P=0.0019)$. A total of 14 samples $(25.0 \%)$, among the 56 conjunctival neoplasia from HIVpositive subjects, tested positive for HPV sequences $(P=0.0312)$. Only $10 \%$ (three out of 30 ) of the neoplastic samples, from HIVnegative subjects, were HPV positive.

The histology of the 86 conjunctival neoplasia patients identified $29(33.7 \%)$ lesions as ICSCC, $23(26.7 \%)$ as CIN3, $18(20.9 \%)$ as CIN2 and $16(18.6 \%)$ as CIN1. The HPV distribution among cases, grouped by histological types, also stratified by HIV serology, are summarised in Table 2. The frequency of HPV infection among HIV-positive patients was 15\% (three out of 20) in the ICSCC, $25 \%$ (three out of 12) in CIN3, 36.3\% (four out of 11) in CIN2 and $33.3 \%$ (four out of 12) in CIN1. HPV sequences among HIVnegative patients were identified in $28.5 \%$ (two out of seven) of CIN2, 25.5\% (one out of four) of CIN1, 4.1\% (one out of 23) of controls and in none of the ICSCC and CIN3 samples. Therefore, HPV detection frequency decreased in more advanced disease stages.

Characterisation of the amplified HPV sequences allowed the identification of two mucosal HPVs (6 and 18 types) and six EV- related HPVs (14b, 20, 38, DL473, PPHL1FR and HPV100). A putative new HPV sequence (CJ198) was identified in one ICSCC and in one CIN1 sample.

\section{DISCUSSION}

Overall, this study suggests that mucosal and EV HPVs do infect the conjunctival epithelium, but does not confirm a role for specific HPVs in the development of conjunctival carcinoma. Furthermore, the low frequency of EV HPV types in ICSCC compared to that found in preneoplastic lesions (CIN1-2) suggests that these HPV types are not involved in tumour progression.

These results are concordant with several others epidemiological studies, performed by broad consensus PCRs, clearly indicating that EV HPV types are commonly found in skin lesions (up to 90\%) from immunosuppressed renal transplant recipients.

The high detection rates of HPV DNA both in healthy skin biopsies, plucked hairs or skin swab samples in immunocompetent (25-65\% HPV-positivity) and in immunosuppressed (30-90\% positivity) individuals may suggest an ubiquity nature of these viruses. Forslund et al (2004), analysing swab samples collected on the top of skin tumours, found HPV DNA in $69 \%$ of the samples against a $12 \%$ HPV positivity within the biopsies of the same tumours; they concluded that HPV positivity in skin tumour biopsies may merely reflect surface contamination by viral DNA or particles harboured in cells shed from infected healthy skin.

In conclusion, we report that in our study on conjunctival neoplasia from sub-Sahara region, cutaneous HPVs were not detected while mucosotropic HPV types have been rarely found. Moreover, EV-related HPVs were frequently identified in lowgrade conjunctival neoplasia of HIV-positive patients but less commonly in invasive conjunctival carcinomas. Thus, HPV DNA found in conjunctival lesions might merely be a passenger.

\section{ACKNOWLEDGEMENTS}

We thank EM de Villiers for helpful suggestions on the manuscript and for providing HPV plasmid clones (HPV type 2, 5, 10 and 38). This work was supported by grants from Ministero della Salute (Progetto Finalizzato 2005-2007) and Ricerca Corrente (2005), and the ICSC-World Laboratory (project MCD-2/7).

\section{REFERENCES}

Ateenyi-Agaba C (1995) Conjunctival squamous-cell carcinoma associated with HIV infection in Kampala, Uganda. Lancet 345: $695-696$

Ateenyi-Agaba C, Weiderpass E, Smet A, Dong W, Dai M, Kahwa B, Wabinga $\mathrm{H}$, Katongole-Mbidde E, Franceschi S, Tommasino M (2004) Epidermodysplasia verruciformis human papillomavirus types and carcinoma of the conjunctiva: a pilot study. $\mathrm{Br}$ J Cancer 90: 1777 - 1779

Beral V, Newton R (1998) Overview of the epidemiology of immunodeficiency-associated cancers. J Natl Cancer Inst Monogr 23: 1-6

Berkhout RJ, Tieben LM, Smits HL, Bavinck JN, Vermeer BJ, ter Schegget J (1995) Nested PCR approach for detection and typing of epidermodysplasia verruciformis-associated human papillomavirus types in cutaneous cancers from renal transplant recipients. J Clin Microbiol 33: $690-695$

Blodi FC (1973) Squamous cell carcinoma of the conjunctiva. Doc Ophthalmol 34: $93-108$

Buonaguro FM, Tornesello ML, Salatiello I, Biryahwaho B, Sempala SDK, Waddell K, Downing R, Buonaguro L, Monaco M, Visciano ML, BethGiraldo E, Giraldo G (2000) Mini-epidemic of conjunctival cancers in
Ugandan subjects during AIDS epidemic. In: Proceeding of XIII Intenational Conference on AIDS, pp 205-213. Bologna: Mondotti

Caldeira S, Zehbe I, Accardi R, Malanchi I, Dong W, Giarre M, de Villiers EM, Filotico R, Boukamp P, Tommasino M (2003) The E6 and E7 proteins of the cutaneous human papillomavirus type 38 display transforming properties. J Virol 77: 2195-2206

de Roda Husman AM, Walboomers JM, van den Brule AJ, Meijer CJ, Snijders PJ (1995) The use of general primers GP5 and GP6 elongated at their $3^{\prime}$ ends with adjacent highly conserved sequences improves human papillomavirus detection by PCR. J Gen Virol 76: 1057-1062

Eng HL, Lin TM, Chen SY, Wu SM, Chen WJ (2002) Failure to detect human papillomavirus DNA in malignant epithelial neoplasms of conjunctiva by polymerase chain reaction. Am J Clin Pathol 117: $429-436$

Forslund O, Antonsson A, Nordin P, Stenquist B, Hansson BG (1999) A broad range of human papillomavirus types detected with a general PCR method suitable for analysis of cutaneous tumours and normal skin. $J$ Gen Virol 80: $2437-2443$

Forslund O, Lindelof B, Hradil E, Nordin P, Stenquist B, Kirnbauer R, Slupetzky K, Dillner J (2004) High prevalence of cutaneous 
human papillomavirus DNA on the top of skin tumors but not in 'stripped' biopsies from the same tumors. J Invest Dermatol 123: $388-394$

Moubayed P, Mwakyoma H, Schneider DT (2004) High frequency of human papillomavirus $6 / 11,16$, and 18 infections in precancerous lesions and squamous cell carcinoma of the conjunctiva in subtropical Tanzania. Am J Clin Pathol 122: 938-943

Newton R, Ziegler J, Ateenyi-Agaba C, Bousarghin L, Casabonne D, Beral V, Mbidde E, Carpenter L, Reeves G, Parkin DM, Wabinga H, Mbulaiteye S, Jaffe H, Bourboulia D, Boshoff C, Touze A, Coursaget P (2002) The epidemiology of conjunctival squamous cell carcinoma in Uganda. $\mathrm{Br} J$ Cancer 87: $301-308$

Resnick RM, Cornelissen MT, Wright DK, Eichinger GH, Fox HS, ter Schegget J, Manos MM (1990) Detection and typing of human papillomavirus in archival cervical cancer specimens by DNA amplification with consensus primers. J Natl Cancer Inst 82: $1477-1484$
Templeton AC (1973) Tumours of the eye and adnexa. In: Tumours of a Tropical Country: a Survey of Uganda 1964-1968, Templeton AC (ed) pp $203-214$. New York: Springer-Verlag

Tornesello ML, Buonaguro FM, Buonaguro L, Salatiello I, Beth-Giraldo E, Giraldo G (2000) Identification and functional analysis of sequence rearrangements in the long control region of human papillomavirus type 16 Af-1 variants isolated from Ugandan penile carcinomas. J Gen Virol 81: $2969-2982$

Wabinga HR, Parkin DM, Wabwire-Mangen F, Nambooze S (2000) Trends in cancer incidence in Kyadondo County, Uganda, 1960-1997. Br J Cancer 82: $1585-1592$

Waddell KM, Lewallen S, Lucas SB, Atenyi-Agaba C, Herrington CS, Liomba G (1996) Carcinoma of the conjunctiva and HIV infection in Uganda and Malawi. Br J Ophthalmol 80: $503-508$

Waring III GO, Roth AM, Ekins MB (1984) Clinical and pathologic description of 17 cases of corneal intraepithelial neoplasia. Am J Ophthalmol 97: 547-559 